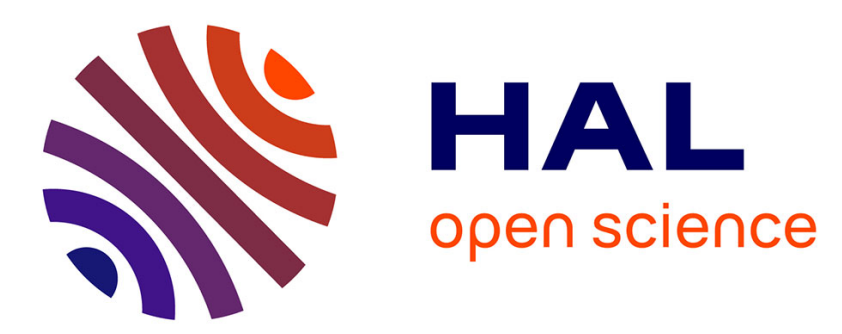

\title{
Rethinking global carbon storage potential of trees. A comment on Bastin et al. (2019)
}

Shawn D. Taylor, Sergio Marconi

\section{To cite this version:}

Shawn D. Taylor, Sergio Marconi. Rethinking global carbon storage potential of trees. A comment on Bastin et al. (2019). Annals of Forest Science, 2020, 77 (2), pp.23. 10.1007/s13595-020-0922-z . hal-03175948

\section{HAL Id: hal-03175948 \\ https://hal.science/hal-03175948}

Submitted on 22 Mar 2021

HAL is a multi-disciplinary open access archive for the deposit and dissemination of scientific research documents, whether they are published or not. The documents may come from teaching and research institutions in France or abroad, or from public or private research centers.
L'archive ouverte pluridisciplinaire HAL, est destinée au dépôt et à la diffusion de documents scientifiques de niveau recherche, publiés ou non, émanant des établissements d'enseignement et de recherche français ou étrangers, des laboratoires publics ou privés. 


\title{
Rethinking global carbon storage potential of trees. A comment on Bastin et al. (2019)
}

\author{
Shawn D. Taylor ${ }^{1,2}$ (D) $\cdot$ Sergio Marconi ${ }^{1}$ \\ Received: 4 October 2019 / Accepted: 10 January 2020 / Published online: 19 March 2020 \\ (C) This is a U.S. government work and not under copyright protection in the U.S.; foreign copyright protection may apply 2020
}

\begin{abstract}
- Key message Bastin et al. 2019 use two flawed assumptions: 1) that the area suitable for restoration does not contain any carbon currently, and 2) that soil organic carbon (SOC) from increased canopy cover will accumulate quickly enough to mitigate anthropogenic carbon emissions. We re-evaluated the potential carbon storage worldwide using empirical relationships of tree cover and carbon. We use global datasets of tree cover, soil organic carbon, and above ground biomass to estimate the empirical relationships of tree cover and carbon stock storage. A more realistic range of global carbon storage potential is between 71.7 and $75.7 \mathrm{GtC}$ globally, with a large uncertainty associated with SOC. This is less than half of the original $205 \mathrm{GtC}$ estimate. The potential global carbon storage of restored forests is much less than that estimated by Bastin et al. 2019. While we agree on the value of assessing global reforestation potential, we suggest caution in considering it the most effective strategy to mitigate anthropogenic emissions. A preprint version of this article was published on 13 August 2019 at https://doi.org/10.1101/730325
\end{abstract}

\section{Main}

Bastin et al. (2019) (hereafter referred to as Bastin 2019) use a novel machine learning based method to model global tree canopy cover potential. After accounting for current tree canopy cover and areas already occupied by urban and agricultural land, they estimate 900 Mha of potential tree canopy cover available worldwide for reforestation. Using biome

Handling Editor: Erwin Dreyer

Contribution of the co-authors

ST conceived of the idea and performed the analysis. ST and SM wrote the manuscript.

A preprint version of this article was published on 13 August 2019 at https://doi.org/10.1101/730325

Shawn D. Taylor

shawn.taylor@usda.gov

Sergio Marconi

sergio.marconi@weecology.org

1 School of Natural Resources and Environment, University of Florida Gainesville, Gainesville, FL, USA

2 U.S. Department of Agriculture, Agricultural Research Service, Jornada Experimental Range, New Mexico State University, Las Cruces, NM, USA specific estimates of tonnes $\mathrm{C}$ per hectare they calculate the global carbon storage potential of this 900 Mha of tree canopy cover. The tonnes $\mathrm{C}$ per hectare values for each biome are derived from average estimates of total carbon storage from two studies of forest (Pan et al. 2011) and tropical grassland (Grace et al. 2006) carbon stock. Thus from their calculation, a hectare of restored tree canopy is equivalent to adding a full hectare of carbon stock potential regardless of the vegetation already in place and results in an overestimate of the global carbon stock potential of restored trees.

To better estimate the relationship between total carbon stock density and tree cover, we randomly sampled locations from four global datasets of (1) aboveground biomass (Woods Hole Research Center 2019), (2) soil organic carbon (SOC) to $1 \mathrm{~m}$ (Hengl et al. 2017), (3) percent tree cover (Hansen et al. 2013), and (4) the corresponding biome (Olson et al. 2001) (Table 1). We further subset these locations to those within protected areas (Levels I-V, UNEP-WCMC and IUCN 2019) to minimize human influence on vegetation development and better represent the full carbon storage potential. Across all biomes, there is already ample carbon stock at all levels of tree cover, and the relationship is weak in several biomes due to the contribution of SOC (Fig. 1). The slope of this relationship is a more accurate representation of the potential carbon stock gained with tree cover. For example in Tropical Grasslands, Bastin 2019 estimate that an additional 0.5 ha of 
Table 1 Estimates of the tonnes $\mathrm{C}$ per hectare relationship and per biome estimate of total carbon storage potential using the original estimates from Bastin 2019, estimates derived using global datasets in the current study, and all estimates adjusted to exclude soil organic carbon. The biome-specific potential tree canopy cover is from Bastin 2019 Table S2

\begin{tabular}{|c|c|c|c|c|c|c|c|c|c|}
\hline \multirow[b]{3}{*}{ Biome } & \multirow[b]{3}{*}{$\begin{array}{l}\text { Potential tree } \\
\text { cover (Mha) }\end{array}$} & \multicolumn{4}{|c|}{ Including soil organic carbon } & \multicolumn{4}{|c|}{ Without soil organic carbon } \\
\hline & & \multicolumn{2}{|c|}{$\begin{array}{l}\text { Tonnes } \mathrm{C} \text { per hectare } \\
\text { increase with } 1 \mathrm{ha} \\
\text { canopy }\end{array}$} & \multicolumn{2}{|c|}{$\begin{array}{l}\text { Total C stock } \\
\text { potential }(\mathrm{GtC})\end{array}$} & \multicolumn{2}{|c|}{$\begin{array}{l}\text { Tonnes C per hectare } \\
\text { increase with } 1 \text { ha } \\
\text { canopy }\end{array}$} & \multicolumn{2}{|c|}{$\begin{array}{l}\text { Total C stock } \\
\text { potential }(\mathrm{GtC})\end{array}$} \\
\hline & & $\begin{array}{l}\text { Bastin } \\
2019\end{array}$ & $\begin{array}{l}\text { Current } \\
\text { study }\end{array}$ & $\begin{array}{l}\text { Bastin } \\
2019\end{array}$ & $\begin{array}{l}\text { Current } \\
\text { study }\end{array}$ & $\begin{array}{l}\text { Bastin } \\
2019\end{array}$ & $\begin{array}{l}\text { Current } \\
\text { study }\end{array}$ & $\begin{array}{l}\text { Bastin } \\
2019\end{array}$ & $\begin{array}{l}\text { Current } \\
\text { study }\end{array}$ \\
\hline Boreal forests/taiga & 178 & 239.2 & -240.4 & 42.6 & -42.8 & 86.1 & 45.3 & 15.3 & 8.1 \\
\hline Deserts and xeric shrublands & 77.6 & 202.4 & 109.2 & 15.7 & 8.5 & 28.5 & 76.9 & 2.2 & 6 \\
\hline Flooded grasslands and savannas & 9 & 202.5 & 375.7 & 1.8 & 3.4 & 28.6 & 63.7 & 0.3 & 0.6 \\
\hline Mangroves & 2.6 & 282.5 & 190.5 & 0.7 & 0.5 & 198.9 & 105.9 & 0.5 & 0.3 \\
\hline $\begin{array}{l}\text { Mediterranean forests, woodlands, } \\
\text { and scrub }\end{array}$ & 18.8 & 202.4 & 154.6 & 3.8 & 2.9 & 28.5 & 85.2 & 0.5 & 1.6 \\
\hline Montane grasslands and shrublands & 19.3 & 202.4 & 136.9 & 3.9 & 2.6 & 28.5 & 120.1 & 0.6 & 2.3 \\
\hline $\begin{array}{l}\text { Temperate broadleaf and mixed } \\
\text { forests }\end{array}$ & 109 & 154.7 & 1.7 & 16.9 & 0.2 & 80.4 & 81 & 8.8 & 8.8 \\
\hline Temperate conifer forests & 35.9 & 154.7 & 106.6 & 5.6 & 3.8 & 80.4 & 108.6 & 2.9 & 3.9 \\
\hline $\begin{array}{l}\text { Temperate grasslands, savannas, and } \\
\text { shrublands }\end{array}$ & 72.5 & 154.7 & 51.1 & 11.2 & 3.7 & 80.4 & 67.4 & 5.8 & 4.9 \\
\hline Tropical coniferous forests & 7.1 & 282.5 & 144.4 & 2 & 1 & 198.9 & 97.9 & 1.4 & 0.7 \\
\hline Tropical dry broadleaf forests & 32.8 & 282.5 & 171.4 & 9.3 & 5.6 & 198.9 & 101.8 & 6.5 & 3.3 \\
\hline $\begin{array}{l}\text { Tropical grasslands, savannas, and } \\
\text { shrublands }\end{array}$ & 189.5 & 282.5 & 137.3 & 53.5 & 26 & 198.9 & 98 & 37.7 & 18.6 \\
\hline Tropical moist broadleaf forests & 97.1 & 282.5 & 139.5 & 27.4 & 13.5 & 198.9 & 150.3 & 19.3 & 14.6 \\
\hline Tundra & 50.6 & 202.4 & -9.9 & 10.2 & -0.5 & 28.5 & 38.6 & 1.4 & 2 \\
\hline Total & & & & 204.6 & $\begin{array}{l}28.4 \\
\quad\left(71.7^{1}\right)\end{array}$ & & & 103.2 & 75.7 \\
\hline
\end{tabular}

${ }^{1} 71.7 \mathrm{GtC}$ is the global potential calculated without considering boreal forests or tundra, as these biomes have a negative relationship between total carbon stock and tree canopy cover

canopy cover (an additional 50\% canopy cover) will add 141.25 tonnes $\mathrm{C}$. The empirical relationship shows an additional $50 \%$ tree cover in this biome means an additional 25.6 tonnes $\mathrm{C} /$ ha on average. Further, the boreal forest and tundra biomes have a negative relationship between carbon stock and tree canopy cover, potentially resulting in a net carbon source if tree canopy cover was added in these biomes. Applying the updated estimates across all 14 biomes results in $28.4 \mathrm{GtC}$ of potential carbon stock if the additional $900 \mathrm{Mha}$ of global tree canopy potential was realized, and $71.7 \mathrm{GtC}$ if the negative contribution from boreal and tundra biomes are removed.

This calculation is further complicated by SOC. SOC makes up the majority of carbon stock in all biomes, and in seven biomes, it has no relationship with tree cover (*p $>0.05$, Fig. 2). In boreal regions (the biome for $19.8 \%$ of the potential canopy area estimated by Bastin 2019), afforestation can cause a temporary increase of greenhouse gas emissions due to quicker SOC mineralization, which can take several decades to recover (Karhu et al. 2011). SOC also forms at rates of less than $0.5 \mathrm{Mg} \mathrm{ha}^{-1}$ year $^{-1}$ in many areas (Trumbore and Harden 1997; Gaudinski et al. 2000; LICHTER et al. 2008), though sometimes up to $1.5 \mathrm{Mg} \mathrm{ha}^{-1}$ year $^{-1}$ (Shi and Han 2014), and it is unreasonable to assume increased tree cover would lead to SOC accumulation at a rate quick enough to effectively mitigate carbon emissions (He et al. 2016). To explore the potential carbon storage of 

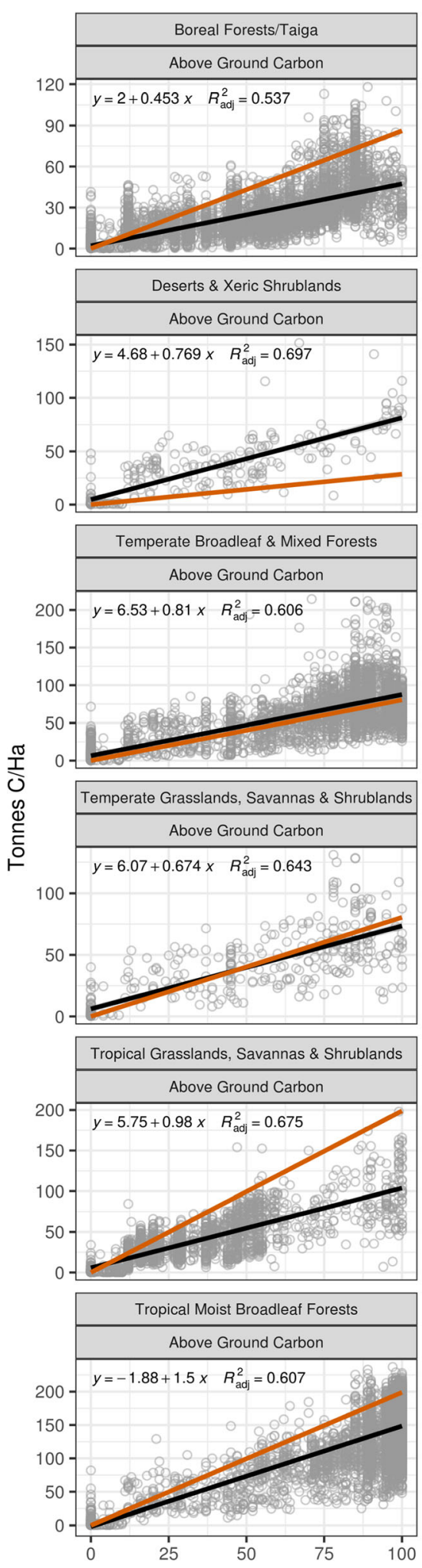
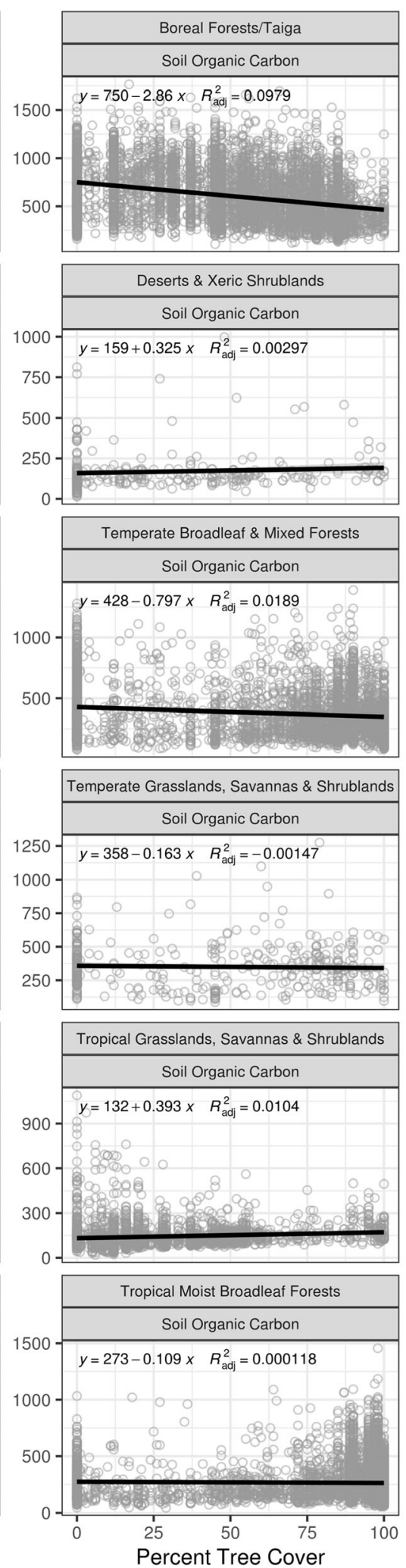
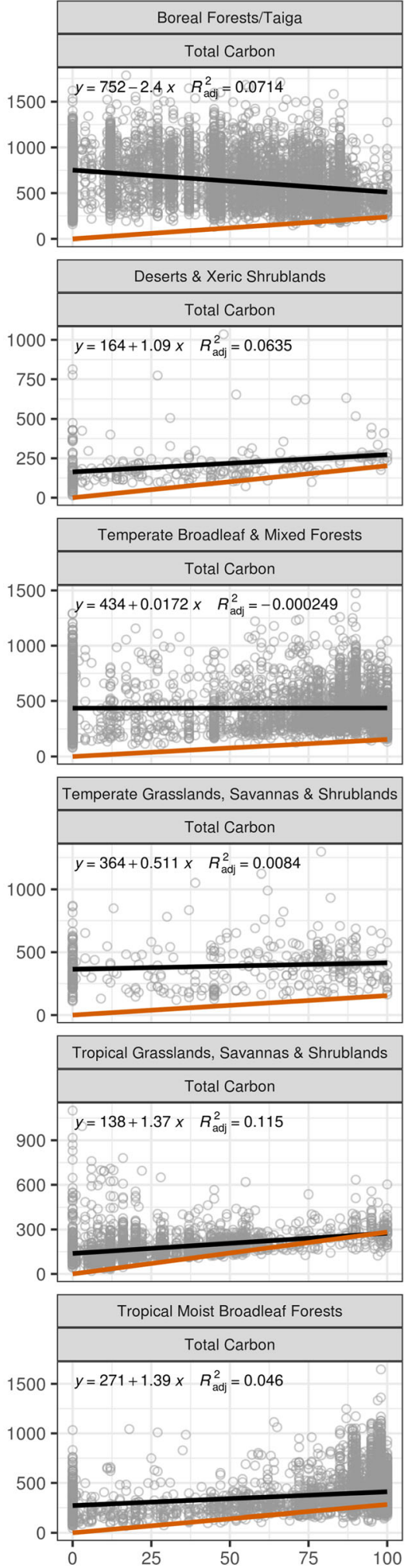

Fig. 1 The relationship between carbon stock and tree cover for 6 of the 14 global biomes using global datasets (black regression line and gray points). The red lines for total carbon indicate the assumed increase in tonnes of $\mathrm{C}$ per hectare for every increase in tree cover in the original analysis, while the red lines in aboveground carbon represents the original estimates minus the fraction of soil organic carbon. The global datasets were randomly sampled for land points within protected areas globally and querying the aboveground biomass, $1 \mathrm{~m}$ soil organic carbon, percent tree cover, and the corresponding biome. Aboveground biomass was converted to carbon stock by multiplying by 0.5 . Total carbon is aboveground carbon plus soil organic carbon for each queried point. Note the difference in scales of the $y$ axis (see Fig. 2 for relationships of all 14 biomes) 
increased global tree cover without considering the complexities of SOC, we adjusted all estimates by removing the contribution of SOC. For the Bastin 2019 estimates, we re-calculated the carbon stock potential minus the SOC fraction using the original sources (Grace et al. 2006; Pan et al. 2011). For our own estimates, we considered only aboveground carbon and its slope with respect to tree cover. With these estimates, the global carbon storage potential is $104 \mathrm{GtC}$ using the re-calculated estimates from Bastin 2019, and 75.7 GtC using the empirical relationships from the global datasets.

Bastin 2019 state that global tree restoration is "the most effective solution" for mitigating climate change. This conclusion uses simple assumptions which ignore complex carbon dynamics, potential feedback loops, societal costs, and carbon saturation as forests mature (see de Coninck et al. 2018 sec. 4.3.7.2 and references therein). For example, some authors consider afforestation and reforestation as an effective mitigation solution only in the tropics since it would reduce albedo in high latitudes (Fuss et al. 2018). Yet, increasing forested areas in the tropics would compete for agriculture and other land use, triggering a number of socio-economic impacts (Fuss et al. 2018). It is also difficult to place the $205 \mathrm{GtC}$ estimate in the context of other mitigation options without a quantitative estimate of the timescale of global forest regrowth, which requires local studies using more nuanced analysis of carbon uptake (e.g., Requena Suarez et al. 2019). Several other comments to Bastin 2019 have raised similar concerns. Namely that the original analysis does not adequately consider SOC, currently in place vegetation, or feedback loops such as fire and changed albedo (Friedlingstein et al. 2019; Lewis et al. 2019; Veldman et al. 2019). Veldman et al. (2019) re-analyzed the Bastin 2019 results using literaturederived values of carbon storage and arrived at a potential $107 \mathrm{GtC}$ from the original 900 Mha of canopy cover. Here, by using biome specific empirically derived relationships of carbon storage and canopy cover from global datasets, we show the potential global carbon storage of restored forests ranges between 71.7 and $75.7 \mathrm{GtC}$, less than $40 \%$ of the original estimate. Along with the other comments, this demonstrates that the original Bastin 2019 estimate was clearly overestimated.

Funding information This research was supported by the Gordon and Betty Moore Foundation's Data-Driven Discovery Initiative through grant GBMF4563 to E.P. White.

Data availability All code and extracted data is archived on Zenodo repository (Taylor 2019) at https://doi.org/10.5281/zenodo. 3364028 .

\section{Compliance with ethical standards}

Conflict of interest The authors declare that they have no conflict of interest.

\section{Appendix}



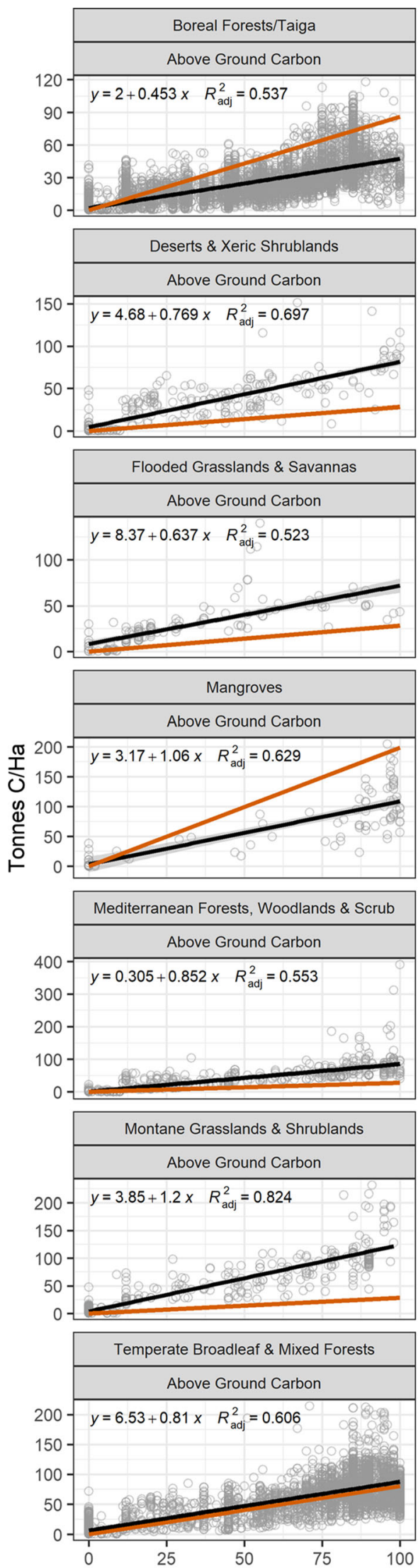

Fig. 2 Carbon stock relationships for all 14 biomes
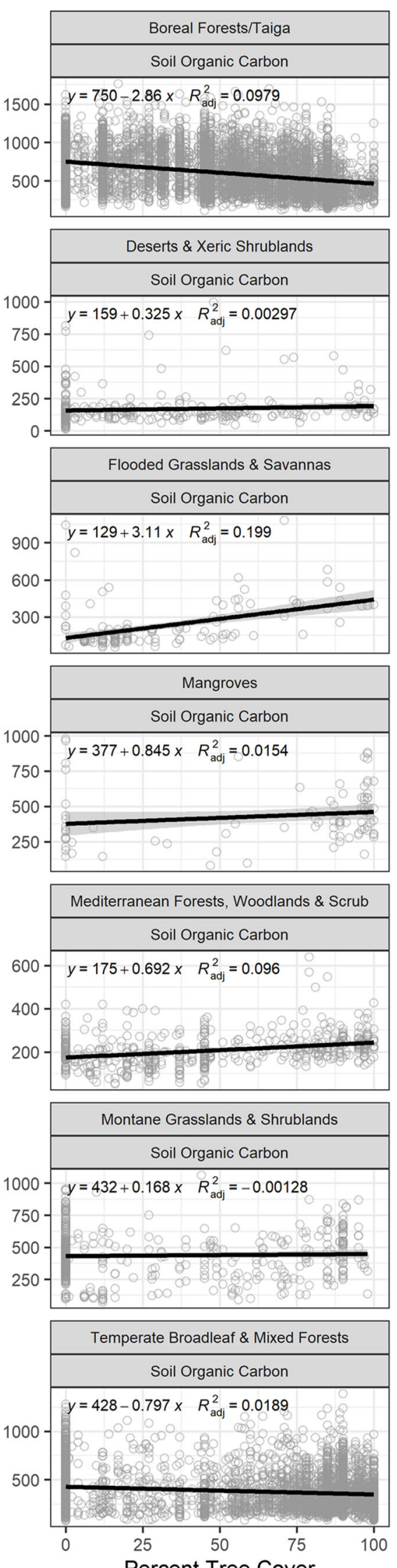

Percent Tree Cover
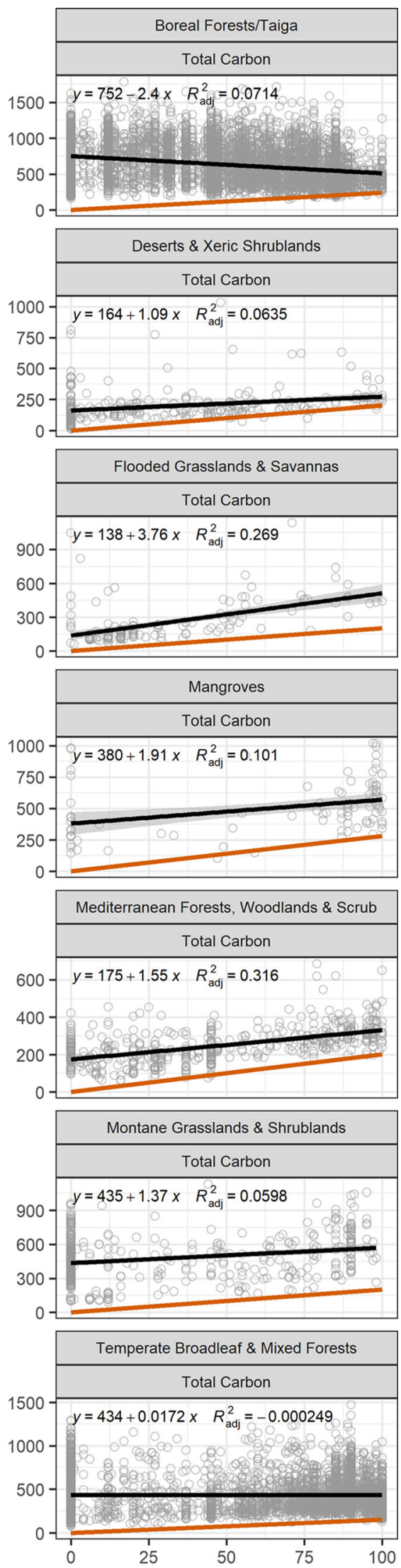

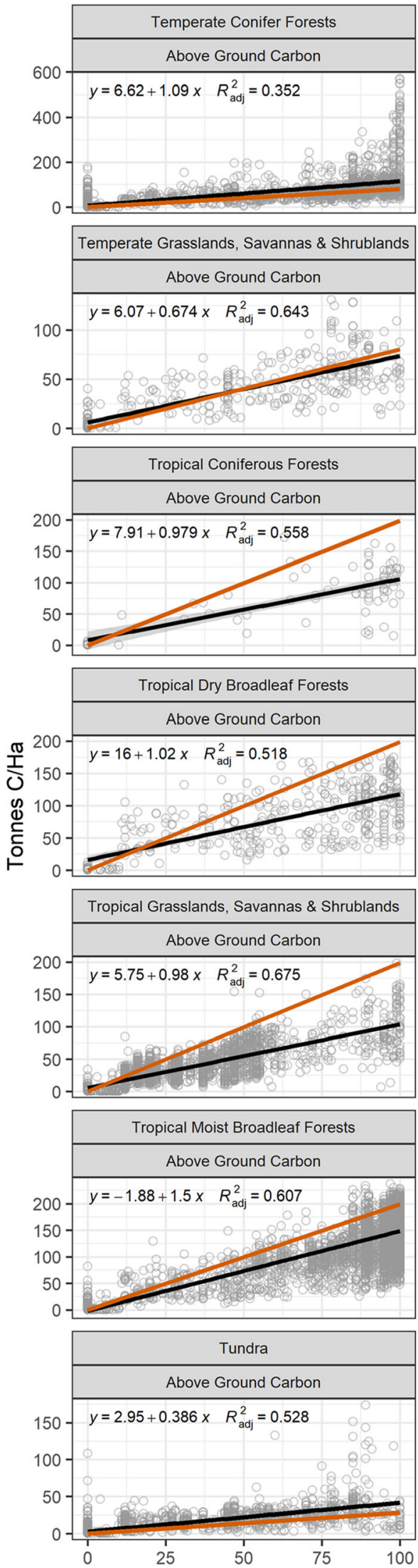

Fig. 2 (continued)

\section{Q springer INRAC}
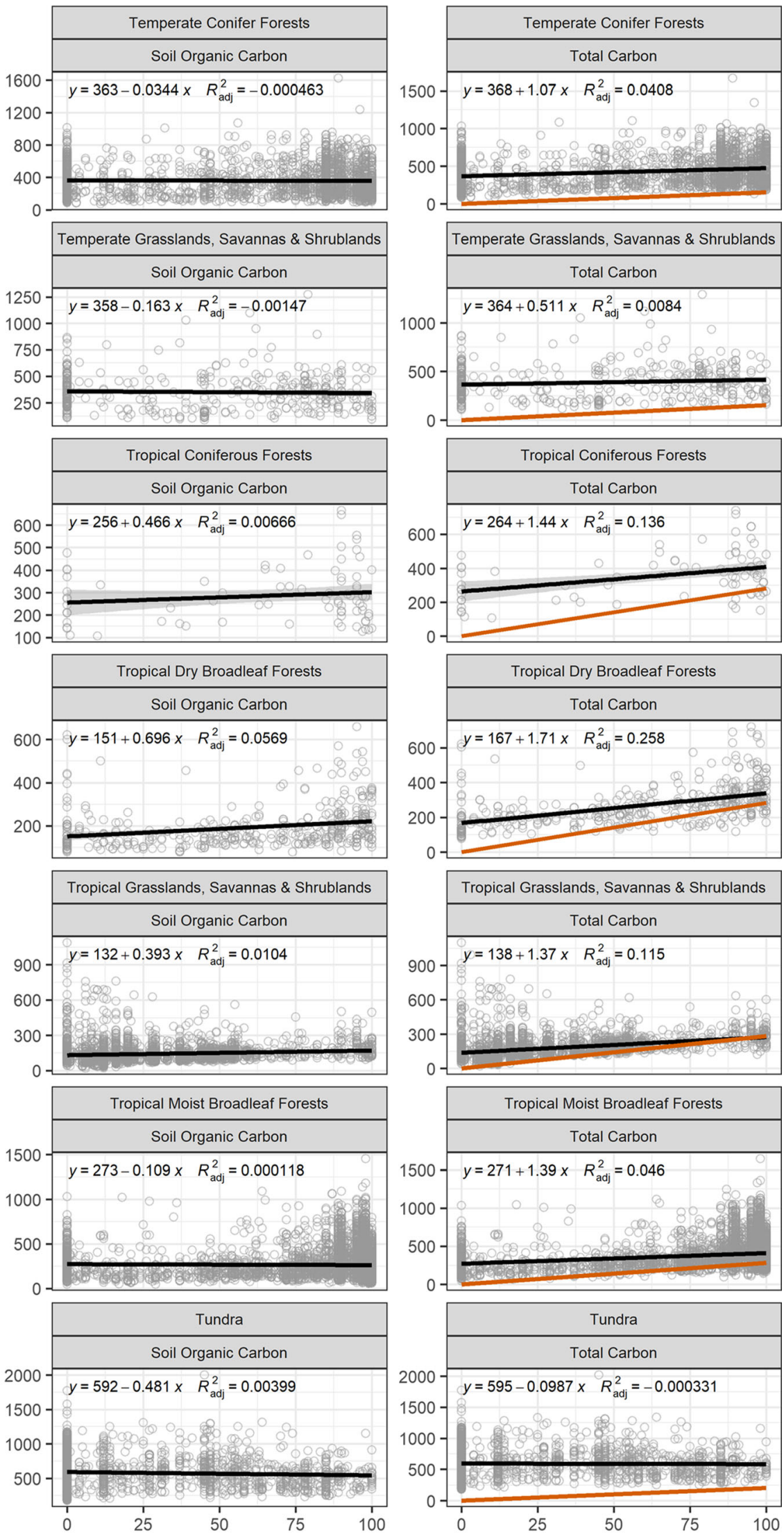

\section{Percent Tree Cover}




\section{References}

Bastin J-F, Finegold Y, Garcia C et al (2019) The global tree restoration potential. Science (80- ) 365:76-79. https://doi.org/10.1126/science. aax0848

de Coninck H, Revi A, Babiker M, et al (2018) Chapter 4: strengthening and implementing the global response. In: IPCC Special Report 2018: Global Warming of $1.5^{\circ} \mathrm{C}$

Friedlingstein P, Allen M, Canadell JG et al (2019) Comment on "The global tree restoration potential.”. Science (80- ) 366:eaay8060. https://doi.org/10.1126/science.aay8060

Fuss S, Lamb WF, Callaghan MW et al (2018) Negative emissions - Part 2: costs, potentials and side effects. Environ Res Lett 13:063002. https://doi.org/10.1088/1748-9326/aabf9f

Gaudinski JB, Trumbore SE, Davidson EA, Zheng S (2000) Soil carbon cycling in a temperate forest: radiocarbon-based estimates of residence times, sequestration rates and partitioning of fluxe. Biogeochemistry 51:33-69. https://doi.org/10.1023/A: 1006301010014

Grace J, Jose JS, Meir P et al (2006) Productivity and carbon fluxes of tropical savannas. J Biogeogr 33:387-400. https://doi.org/10.1111/j. 1365-2699.2005.01448.x

Hansen MC, Potapov PV, Moore R et al (2013) High-resolution global maps of 21st-century forest cover change. Science (80- ) 342:850 853. https://doi.org/10.1126/science.1244693

He Y, Trumbore SE, Torn MS et al (2016) Radiocarbon constraints imply reduced carbon uptake by soils during the 21 st century. Science (80) 353:1419-1424. https://doi.org/10.1126/science.aad4273

Hengl T, Mendes de Jesus J, Heuvelink GBM, Ruiperez Gonzalez M, Kilibarda M, Blagotić A, Shangguan W, Wright MN, Geng X, Bauer-Marschallinger B, Guevara MA, Vargas R, MacMillan R, Batjes NH, Leenaars JG, Ribeiro E, Wheeler I, Mantel S, Kempen B (2017) SoilGrids250m: global gridded soil information based on machine learning. PLoS One 12:e0169748. https://doi.org/10.1371/ journal.pone.0169748

Karhu K, Wall A, Vanhala P et al (2011) Effects of afforestation and deforestation on boreal soil carbon stocks - comparison of measured C stocks with Yasso07 model results. Geoderma 164:33-45. https://doi.org/10.1016/j.geoderma.2011.05.008
Lewis SL, Mitchard ETA, Prentice C et al (2019) Comment on "The global tree restoration potential.”. Science (80- ) 366:eaaz0388. https://doi.org/10.1126/science.aaz0388

LICHTER J, BILLINGS SA, ZIEGLER SE et al (2008) Soil carbon sequestration in a pine forest after 9 years of atmospheric $\mathrm{CO} 2$ enrichment. Glob Chang Biol 14:2910-2922. https://doi.org/10. $1111 / j .1365-2486.2008 .01701 . x$

Olson DM, Dinerstein E, Wikramanayake ED et al (2001) Terrestrial ecoregions of the world: a new map of life on earth: a new global map of terrestrial ecoregions provides an innovative tool for conserving biodiversity. Bioscience 51:933-938

Pan Y, Birdsey RA, Fang J et al (2011) A large and persistent carbon sink in the world's forests. Science (80- ) 333:988-993. https://doi.org/ 10.1126/science. 1201609

Requena Suarez D, Rozendaal DMA, De Sy V et al (2019) Estimating aboveground net biomass change for tropical and subtropical forests: refinement of IPCC default rates using forest plot data. Glob Chang Biol gcb 14767. https://doi.org/10.1111/gcb.14767

Shi S, Han P (2014) Estimating the soil carbon sequestration potential of China's Grain for Green Project. Glob Biogeochem Cycles 28: 1279-1294. https://doi.org/10.1002/2014GB004924

Taylor S (2019) Code for: Rethinking global carbon storage potential of trees. A comment on Bastin et. al 2019.V1. Zenodo. [Dataset]. http://doi.org/10.5281/zenodo.3364028

Trumbore SE, Harden JW (1997) Accumulation and turnover of carbon in organic and mineral soils of the BOREAS northern study area. J Geophys Res Atmos 102:28817-28830. https://doi.org/10.1029/ 97JD02231

UNEP-WCMC and IUCN (2019) Protected Planet: the World Database on Protected Areas (WDPA) Aug/2019

Veldman JW, Aleman JC, Alvarado ST et al (2019) Comment on "The global tree restoration potential.”. Science (80- ) 366:eaay7976. https://doi.org/10.1126/science.aay7976

Woods Hole Research Center. (2019). Aboveground live woody biomass density. Accessed July 6, 2019. http://climate.globalforestwatch.org

Publisher's note Springer Nature remains neutral with regard to jurisdictional claims in published maps and institutional affiliations. 